\title{
Periodontal disease and vasculogenic erectile dysfunction: a lon- gitudinal health-examinee cohort study in South Korea
}

\author{
Jae-Hong Lee ${ }^{1 \dagger}$, Yeon-Tae Kim ${ }^{1 \dagger}$, Jung-Kyu Choi ${ }^{2}$, Seong-Nyum Jeong ${ }^{1}$, and Seong-Ho Choi ${ }^{3 *}$ \\ ${ }^{1}$ Department of Periodontology, Daejeon Dental Hospital, Wonkwang University College of Dentistry, Daejeon 35233, \\ Republic of Korea \\ ${ }^{2}$ Department of Health Insurance Research, Ilsan Hospital, National Health Insurance Service, Goyang 10444, Republic \\ of Korea \\ ${ }^{3}$ Department of Periodontology, Research Institute for Periodontal Regeneration, Yonsei University College of Dentistry, \\ Seoul 03722, Republic of Korea
}

(Received Apr 18, 2017; Revised version received Jun 14, 2017; Accepted Jun 20, 2017)

\begin{abstract}
Data was collected for the period 2002 and 2013, from The National Health Insurance Service Health-Examinee Cohort Database, to evaluate the association between periodontal disease (PD) and vasculogenic erectile dysfunction (VED). Univariate and multivariate logistic regression models applied to a longitudinal retrospective database assessed the association between PD and VED, while adjusting for confounders of socio-demographic factors (age, household income, insurance status, health status, residence area, and smoking status) and systemic disease (cerebral infarction, myocardial infarction, angina pectoris, hypertension, diabetes mellitus, osteoporosis, lipid metabolism disturbances, and obesity). The univariate analysis revealed that VED was positively and significantly related to PD (OR = 2.07; 95\% CI 1.73-2.49; $\mathrm{P}<0.001)$. This was confirmed in the multivariate analysis, after adjusting for socio-demographic and systemic disease $(\mathrm{OR}=1.45 ; 95 \% \mathrm{CI} 1.21-1.75 ; \mathrm{P}<0.001)$. Using information from a longitudinal retrospective cohort database and considering the limitations of this study, we found positive and significant associations between PD and VED. Further studies are required to assess the mechanism underlying the association between PD and VED.
\end{abstract}

KEY WORDS: Cohort, Erectile dysfunction, Periodontal disease

\section{서 론}

치주질환은 치조골, 백악질, 치주인대, 치은을 아우르는 치아 주위 조직의 포괄적인 염증성 파괴로 정의되며, 전 세계 인구의 절반 이상이 이환되어 있는 것으로 보고되는 매우 유병률 높은 만성 질환이다[1]. 국내에서는 2015년 현재 치은염 및 치주질환으로 치과에 내원한 외래 환자 수 가 1,300 만 명을 넘어섰으며, 외래 질환 중 요양급여지출 총액은 급성 기관지염보다 많은 1 조원을 넘어서고 있다.

\footnotetext{
†These authors contributed equally to this work.

*Corresponding author: Seong-Ho Choi

Department of Periodontology, Yonsei University College of Dentistry,

50 Yonsei-ro, Seodaemun-gu, Seoul 03722, Republic of Korea

Tel.: +82-2-2228-3189, Fax: +82-2-392-0398

E-mail: shchoi726@yuhs.ac
}

특히, 2013년 예방 스케일링의 보험 확대 이후, 우리나라 에서의 치주질환의 진단 및 치료에 대한 관심이 지속적으 로 높아지고 있으며, 이에 따라 치과에 내원하여 치주질환 진단을 받고 치료를 받는 환자 수가 연간 평균 $16.7 \%$ 씩 증가하고 있다[2].

미국국립보건원은 발기부전을 성생활을 영위하는데 있 어서 충분히 발기가 되지 않거나 유지되지 않은 상태로 정 의하였으며, 이러한 상태가 3 개월 이상 지속되었을 경우에 일반적인 질환의 의미의 발기부전으로 정의하였다[3]. 전 세계적으로 1 억 명 이상의 성인 남성이 경도에서 중증도 에 이르는 발기부전을 가지고 있는 것으로 예상되며, 한국 인에 있어서는 $40 \%$ 이상의 성인에서 발기부전을 보이는 것으로 보고되었다[4]. 발기부전은 일반적으로 40세 이상 에서 높은 유병률을 보이며, 특히, 40 대에서 70 대 사이의 남성 중 $10 \%$ 가까이는 중증의 발기부전을 가지고 있는 것 
으로 보고되었다[5]. 발기부전은 심인성, 혈관성, 신경성, 내분비성, 대사증후군, 약물부작용, 의인성 등의 원인으로 유발될 수 있으며, 이 중 동맥과 정맥을 포함하는 혈관성 이 발기부전의 주요 원인으로 보고되고 있다[6].

최근 들어 치주질환이 생활습관병을 포함하는 다양한 전신질환과 위험인자나 위험지시자를 공유한다는 사실이 밝혀지기 시작하였으며, 이에 따라서 수많은 역학적, 실험 적 연구들이 진행되었다. 이러한 연구들을 통하여 치주질 환과 심혈관질환, 당뇨, 만성폐쇄성폐질환, 태아관련 질환 과의 연관성이 상당 부분 밝혀졌으며, 혈관성 발기부전과 치주질환과의 연관성 역시 보고되었다[7,8]. 혈관성 발기 부전을 유발하는 주요 위험인자로는 심혈관질환, 당뇨, 흡 연, 고혈압, 비만 등이 있으며, 이들 위험인자들에 대한 연 구 역시 상당부분 이루어져 있다[9]. 심혈관질환을 가지고 있는 경우, 발기부전의 유병률이 $75 \%$ 까지 증가하는 것으로 보고되었으며, 이러한 연구들을 통해서 심혈관질환과 발기 부전과의 직접적인 연관성이 상당부분 확인되었다[10]. 그러 나 이에 반해서, 치주질환과 혈관성 발기부전의 연관성에 대 한 환경학적, 역학적, 실험적 근거가 명확하지 않으며, 특히, 한국에서의 역학적 연구는 더욱 부족한 실정이다.

국민건강보험공단은 2016년 국가 일반 건강검진 수검자 중 40세 이상의 성인을 대상으로 하는 건강검진코호트 빅 데이터 데이터베이스를 발표하였다. 이는 2002년 건강보 험 자격 유지자 중 수검자 51 만명을 무작위 단순 추출한 데이터로 한국인에 있어서 역학적 질환 연구에 유용한 정 보를 줄 것으로 기대되나, 아직 이를 이용하여 치주질환과 혈관성 발기부전의 연관성을 살펴본 연구는 없었다. 이에 본 연구는 국민건강보험공단 건강검진코호트 데이터베이 스를 이용하여 한국 성인 남성에 있어서의 치주질환과 혈 관성 발기부전의 연관성을 살펴보고자 한다.

\section{재료 및 방법}

\section{연구 자료 수집}

본 연구는 National Health Insurance Sharing Service에 서 제공하는 건강검진코호트 데이터베이스를 이용하였다. 본 데이터베이스는 2002 년 말 기준으로 40 에서 79 세의 건 강보험 자격 대상자 약 515 만 명 중, 단순 임의 추출법 (simple random sampling)으로 선택된 10\%인 514,866명을 대상으로 하였다. 2002년 당시, 의료급여수급권자는 일반 건강검진 대상자가 아니었기 때문에, 2002년 연구 대상자 에서는 제외하였다. 본 데이터베이스는 자격 및 소득정보, 병/의원 이용 내역, 질환 이환 내역 및 비용 (청구자료), 흡 연/음주/비만/운동 및 신체활동을 포함하는 건강검진결과, 요양기관 정보를 포함하고 있으며, 이들 자료를 개인식별
이 불가능한 코드로 바꾸어 코호트 형식으로 구축하였다.

본 연구는 관찰 연구를 대상으로 하는 STOBE guidelines (www.strobe-statement.org)를 준수하였으며, 원광대학교 대전치과병원 윤리위원회의 심의를 통과하였다 (승인번호 W1612/001-001). 또한 본 연구는 국민건강보험공단의 표 본코호트 데이터베이스를 활용한 연구로, 연구의 결과는 국민건강보험공단과 관련이 없음을 밝힌다 (연구관리번호 NHIS-2017-2-308).

\section{인구사회학적 요인}

본 연구에서는 건강검진코호트 정보 중 연령 (40-79세, 10 세 단위), 소득분위 (1-5분위, 지역 및 직장 가입자 소득 을 5 분위 그룹화), 가입자구분 (지역가입자/직장가입자), 거주유형 (대도시/기타, 대도시는 100 만 명 이상의 거주자 기준), 장애유형 (정상/중증 [1-2등급]/경증 [3-6등급], 장애 등급을 장애인복지법 시행규칙 장애등급표에 따라서 그룹 화)의 자격 데이터베이스와 건강검진 데이터베이스 중 흡 연유무를 기본 정보로 이용하였다.

\section{치주질환의 진단}

2002년부터 2013년까지의 건강검진코호트 정보 중 진료 데이테베이스의 진료 상병명 (주상병명, 부상병명 포함)으 로 치주질환으로 진단 (급성치주염 [K05.2], 만성치주염 [K05.3], 치주증 [K05.4], 기타 치주질환 [K05.5], 상세불명 의 치주질환 [K05.6])을 받고, 동시에, 구강건강검진 결과 치주질환으로 진단을 받은 경우 본 연구의 치주질환으로 정의하였다. 탐침시 출혈 유무, 치주낭 깊이 (변연치은부 터 골소실 부위까지의 탐침 깊이), 임상적 부착 소실 유무 (백악법랑경계부터 골소실 부위까지의 탐침 깊이), 임상적 치은 염증 소견 유무 (부종과 발적), 방사선학적 골소실량 유무 등이 평가되었으며, 1999년 Centers for Disease Control and Prevention/American Academy of Periodontology (CDC/ $\mathrm{AAP})$ 기준에 근거하여 치주질환이 진단되었다 $[11,12]$.

\section{혈관성 발기부전의 진단}

2002년 이전 혈관성 발기부전으로 진단을 받은 경우는 제외하였으며, 2002년부터 2013년까지의 건강검진코호트 정보 중 진료 데이테베이스의 진료 상병명 (주상병명, 부 상병명 포함)으로 혈관성 발기부전으로 처음 진단 (기질적 원인에 의한 발기부전 [N48.4])을 받은 경우 본 연구의 혈 관성 발기부전으로 정의하였다.

\section{통계학적 분석}

치주질환과 독립 변수들간의 연관성을 보기 위해서 카 이제곱 검정을 이용하였으며, 유의수준은 0.05 로 하였다. 치주질환과 혈관성 발기부전 사이의 연관성을 알아보기 
위하여, 연령, 소득분위, 가입자구분, 거주유형, 장애유형, 흡연여부와 심근경색, 뇌경색, 협심증을 포함하는 심혈관 질환, 고혈압, 당뇨, 골다공증, 비만을 독립변수로 하는 단 변량, 다변량 로지스틱 회귀분석을 시행하였다. SAS 통계 프로그램(version 9.2, SAS Institute, Cary, NC, USA)을 이 용하여 국민건강보험공단 일산병원 정책연구부에서 분석하 였으며 신뢰구간은 $95 \%$, 유의수준은 0.05 로 설정하였다.

\section{결 과}

\section{연구 참여자와 제외자 정보}

Fig. 1 에서와 같이 본 연구의 참여자, 제외자가 설정되었 다. 총 514,866명의 건강검진코호트 표본 전체에서 우선, 구강검진 비수검자 및 여성 159,778 명 $(31.0 \%)$ 이 제외되 고 총 355,088 명이 조사되었다. 상병코드와 구강검진 둘 모두에서 치주질환 진단을 받은 사람은 224,649 명이었으 며, 여기에 해당되지 않아 치주적으로 건강하다고 진단된 사람은 130,439 명이었다. 치주질환과 혈관성 발기부전으 로 동시에 진단받은 사람은 2,043 명이었으며, 혈관성 발기 부전만을 진단받은 사람은 총 1,243 명으로 조사되었다.

\section{치주질환자의 기본 정보}

총 224,649 명의 치주질환자 중, 연령은 40 대가 116,499 명 $(51.9 \%)$ 로 제일 많았다. 50 대가 그 다음이었으며, 나이 가 많을수록 치주질환 진단을 받은 사람의 수는 줄어들었 다. 소득은 5 분위가 82,467 명 $(36.7 \%)$ 로 제일 많았으며, 소 득분위가 줄어들수록 치주질환 진단 역시 줄어들었다. 직 장가입자가 152,144 명 (67.6\%), 100 만 명 미만의 도시와 농어촌에 거주하는 경우가 136,894 명 (60.9\%)를 보였으며, 장애인복지법의 장애등급표에 따라서 정상인 경우가 223,724 명 $(99.6 \%)$ 로 대부분을 차지하였다. 흡연의 경우 $24.8 \%$ 인 55,743 명이 현재 흡연하고 있다고 응답하였다

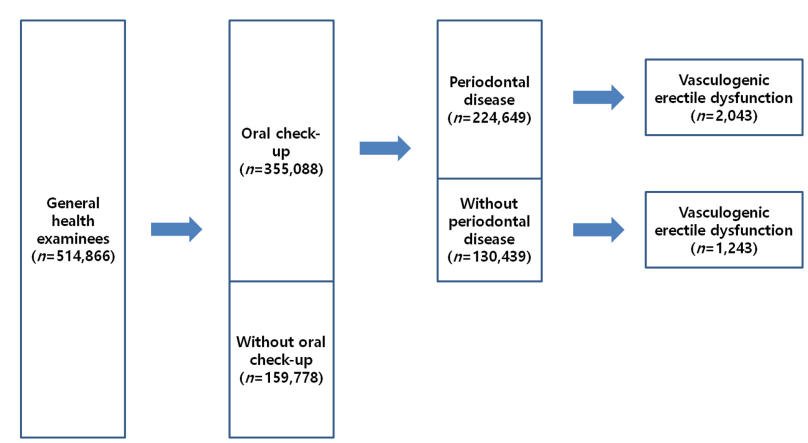

Fig. 1. Flow chart of the inclusion and exclusion of participants in the National Health Insurance Service- Health Examinee Cohort during 2002-2013.
Table 1. Baseline characteristics of the population included in the National Health Insurance Service-Health Examinee Cohort (NHISHEC) according to vasculogenic erectile dysfunction patients with periodontal disease

\begin{tabular}{lcc}
\hline \multicolumn{1}{c}{ Characteristics } & No. of subjects & Percentage (\%) \\
\hline Total & 224,649 & 100 \\
Age group (years) & & \\
$\quad 40-49$ & 116,499 & 51.9 \\
$50-59$ & 65,228 & 29.0 \\
$60-69$ & 34,645 & 15.4 \\
$70-79$ & 8,277 & 3.7 \\
Household income & & \\
First quintile & 32,694 & 14.6 \\
$\quad$ Second quintile & 29,489 & 13.1 \\
Third quintile & 33,736 & 15.0 \\
Fourth quintile & 46,263 & 20.6 \\
$\quad$ Fifth quintile & 82,467 & 36.7 \\
Insurance status & & \\
$\quad$ NHIS (self-employed) & 72,505 & 32.3 \\
$\quad$ NHIS (employees) & 152,144 & 67.7 \\
Residence area ${ }^{\dagger}$ & & \\
Metropolitan & 87,755 & 39.1 \\
$\quad$ Others & 136,894 & 60.9 \\
Health status & & \\
$\quad$ Healthy & 223,724 & 99.6 \\
Major condition & 316 & 0.1 \\
Minor condition & 609 & 0.3 \\
Smoking & 55,743 & 24.8 \\
\hline N & 5 S Nation &
\end{tabular}

NHIS, National Health Insurance Service

*Quintiles based on the insurance fee imposed on each household, with beneficiaries of the medical aid program classed into the first quintile.

Classified with a cutoff of one million residents.

(Table 1).

\section{인구사회학적 요인과 치주질환의 연관성}

치주질환자를 대상으로 인구사회학적 요인을 단변량 로 지스틱 회귀분석을 이용하여 산출하였다(Table 2). 분석결 과 연령은 40대를 기준으로 79세까지 나이가 많을수록 더 낮은 오즈비를 나타내었다. 소득의 경우는, 1 분위 소득분 위를 기준으로 하였을 때, 소득이 제일 높은 5 분위에서 오 즈비 1.32 (95\% 신뢰구간 $1.26-1.37, P<0.001)$ 로 제일 높 은 값을 나타내었다. 지역가입자를 기준으로 하였을 때, 직장가입자는 오즈비 1.37 (95\% 신뢰구간 1.33-1.41, $P<$ 0.001)을 나타내었고, 대도시를 기준으로 하였을 때, 그 외 지역 거주자는 오즈비 0.71 (95\% 신뢰구간 0.68-0.74, P < $0.001)$ 을 나타내었다. 장애가 없을 경우를 기준으로 하였 을 때, 중증 (오즈비 $0.73,95 \%$ 신뢰구간 $0.55-0.98, P=$ 0.036 )이나 경증 (오즈비 $0.80,95 \%$ 신뢰구간 $0.65-0.99, P$ $=0.035)$ 의 장애가 있을 때보다 높은 오즈비를 보였다. 
Table 2. Association of vasculogenic erectile dysfunction patients with periodontal disease in univariate regression analysis

\begin{tabular}{|c|c|c|c|}
\hline Characteristics & OR & $95 \% \mathrm{CI}$ & $\mathrm{P}^{*}$ \\
\hline \multicolumn{4}{|l|}{ Age group (ref: 40-49) } \\
\hline $50-59$ & 1.00 & $0.96-1.03$ & 0.892 \\
\hline $60-69$ & 0.50 & $0.48-0.52$ & $<0.001$ \\
\hline $70-79$ & 0.16 & $0.16-0.17$ & $<0.001$ \\
\hline \multicolumn{4}{|c|}{ Household income (ref: First quintile) } \\
\hline Second quintile & 1.01 & $0.96-1.06$ & 0.774 \\
\hline Third quintile & 1.08 & $1.03-1.13$ & 0.002 \\
\hline Fourth quintile & 1.15 & $1.10-1.20$ & $<0.001$ \\
\hline Fifth quintile & 1.32 & $1.26-1.37$ & $<0.001$ \\
\hline \multicolumn{4}{|c|}{ Insurance status (ref: Self-employed) } \\
\hline NHIS (employees) & 1.37 & $1.33-1.41$ & $<0.001$ \\
\hline \multicolumn{4}{|c|}{ Residence area (ref: Metropolitan) } \\
\hline Others & 0.71 & $0.68-0.74$ & $<0.001$ \\
\hline \multicolumn{4}{|c|}{ Health status (ref: Healthy) } \\
\hline Major condition & 0.73 & $0.55-0.98$ & 0.036 \\
\hline Minor condition & 0.80 & $0.65-0.99$ & 0.035 \\
\hline
\end{tabular}

$\mathrm{OR}$, odd ratio; $\mathrm{CI}$, confidence interval

*Boldface denotes statistical significance $(P<0.05)$.

\section{치주질환과 혈관성 발기부전의 연관성}

치주질환과의 연관성을 알아보기 위한 단변량 로지스틱 회귀분석 결과 혈관성 발기부전은 발기부전이 없을 때에 비하여, 2.07 (95\% 신뢰구간 1.73-2.49, $P<0.001)$ 의 오즈 비를 나타내었다. 다변량 로지스틱 회귀분석에서는 연령, 소득분위, 가입자구분, 거주유형, 장애유형의 인구사회학 적 요인과 흡연여부, 심근경색, 뇌경색, 협심증을 포함하는 심혈관질환, 고혈압, 당뇨, 골다공증, 비만을 보정하였다. 보정에 사용된 전신질환은 주상병 또는 부상병으로 고혈 압 (I10, I15), 당뇨 (E10-E14), 골다공증 (M08-M82), 뇌경 색 (I63-I66), 협심증 (I20), 심근경색 (I21-I22), 지질단백대 사장애 (E78), 및 비만 (E66)으로 진단을 받은 경우에 한 하였다. 분석 결과, 혈관성 발기부전이 없을 때에 비하여,

Table 3. Association of vasculogenic erectile dysfunction patients with periodontal disease in multivariate regression analysis with adjustment for confounding factors

\begin{tabular}{lccc}
\hline \multicolumn{1}{c}{ Characteristics } & OR & $95 \%$ CI & $\mathrm{P}^{*}$ \\
\hline Univariate (ref: Normal) $^{*}$ & 2.07 & $1.73-2.49$ & $<0.001$ \\
Multivariate $^{\dagger}$ (ref: Normal) & 1.45 & $1.21-1.75$ & $<0.001$
\end{tabular}

OR, odd ratio; $\mathrm{CI}$, confidence interval

*Boldface denotes statistical significance $(P<0.05)$.

Multivariate logistic regression adjusted for the confounders of socio-demographic factors (age, household income, insurance status, health status, residence area, and smoking status) and systemic disease (cerebral infarction, myocardial infarction, angina pectoris, hypertension, diabetes mellitus, osteoporosis, lipid metabolism disturbances, and obesity).
1.45 (95\% 신뢰구간 $1.21-1.75, P<0.001)$ 의 오즈비로 단 변량 분석 값에 비하여 낮은 값을 보였다(Table 3).

\section{교 찰}

본 연구 결과, 치주질환은 중년일수록 (40-59세), 소득이 높을수록, 대도시에 거주할수록, 그리고 장애가 없을수록 높은 오즈비를 보였다. 이는 고령과 낮은 소득, 농어촌지 역, 그리고 장애가 있을수록 높은 치주질환 유병률을 보인 다는 일반적인 표본 연구들과는 상반되는 결과이다[13]. 이렇게 지금까지의 역학적 연구결과와 상반되는 결과를 보이는 이유는 본 연구가 전국민 중 일반 건강검진과 구 강검진 수검자만을 대상으로 하였기 때문으로 고려된다. 즉, 건강검진 수검자만이 연구 샘플이 되기 때문에, 소득 이 적거나 농어촌 등의 의료기관 접근이 어려운 곳에 거 주하는 경우, 수검률이 떨어질 것으로 예상된다. 또한, 장 애 등급이 높을수록 건강검진 수검률은 급격히 떨어지기 때문에 본 연구의 인구사회학적 결과와 일치한다고 할 수 있다[14].

Keller 등[15]은 단면연구를 통해서 치주질환과 발기부 전의 오즈비 3.35 (95\% 신뢰구간 3.25-3.45, $P<0.001)$ 를 보고하였고, Oguz 등[16]은 무작위대조연구에서 3.29 (95\% 신뢰구간 $1.36-9.55, P<0.001)$ 의 오즈비를 보고하 였다. 국내에서는 치주질환과 혈관성 발기부전과의 관계 를 100 만 명 이상의 대규모 표본코호트연구를 통해 조사 한 결과 단변량 분석에서 2.75 (95\% 신뢰구간 2.55-2.97, $P<0.001)$ 의 오즈비를, 인구사회학적 요소와 주요 생활습 관병을 통제한 다변량 분석에서는 1.53 (95\% 신뢰구간 $1.41-1.65, P<0.001)$ 의 오즈비를 보였다[17]. 이는 한국 인에 있어서 심혈관질환, 당뇨, 류마티스관절염, 골다공증, 비만보다도 더 높은 연관성을 보이는 결과이다. 또한, 치 주판막술과 골유도재생술을 포함하는 치주수술을 시행한 치주질환자를 표본코호트에서 조사한 결과, 주요 위험요 소를 통제한 다변량 분석에서 1.29 (95\% 신뢰구간 1.06$1.58, P=0.002)$ 의 오즈비를 보였다[18]. 본 연구에서도 단변량 분석 결과 $2.07(95 \%$ 신뢰구간 $1.73-2.49, P<$ $0.001)$ 의 오즈비를, 흡연여부를 포함하여 인구사회학적 요 인과 주요 심혈관계, 및 전신질환을 통제한 다변량 분석 결과는 1.45 (95\% 신뢰구간 $1.21-1.75, P<0.001)$ 의 오즈 비로 앞서 조사한 연구 결과와 유사한 결과를 보였다.

구강 내 치주질환에 의해서 병적으로 증가하는 치주질 환균, 특히, Porphyromonas gingivalis (P.gingivalis)는 치주 조직에 만성 염증을 유도하는 것으로 보고되고 있다[19]. 이러한 구강 내 국소적인 염증반응으로 인하여 타액이나 치은열구 삼출물 등에서 염증성 사이토카인인 Tumor 
necrosis factor- $\alpha$, interleukin- 6 와 8, C-reactive protein이 높은 농도로 발현되며, 이러한 염증성 물질들의 혈관계 침 투 및 순환은 전신적인 염증 반응을 발현하는 것으로 보 고되었다[20]. 특히, P.gingivalis의 DNA가 혈관의 내피세 포에 발생한 죽종(atheroma)에서 발견되었음이 보고되었 으며, 이러한 사실은 병적인 치주질환균이 죽상동맥경화 증과 밀접한 관련을 보임을 확인한 연구 결과이다[21]. Zuo 등[22]은 만성 치주질환이 전신적인 염증 반응을 일 으키고 내피세포를 손상시켜 혈관 내피 산화질소합성을 감소시킴을 보고하였다. 따라서 발기의 생리적 과정에 필 요한 산화질소의 합성과 분비에 주요한 역할을 하는 내피 세포의 손상이 혈관성 발기부전을 유발하는 주요 기전으 로 인지되고 있다[23].

치주질환의 치료가 내피기능의 개선에 도움을 줄 수 있 음이 여러 연구를 통해 확인되고 있다. Tonetti 등[24]은 치 주질환의 치료가 6개월 뒤 내피기능의 개선을 보였다고 보고하였으며, Eltas 등[25]도 치주치료가 내피기능의 이상 을 회복시키는 데 도움을 준다고 보고하였다. 이러한 사실 들을 바탕으로 할 때, 치주질환균으로 인한 전신 염증의 발생은 내피기능의 약화와 죽상동맥경화증을 발생시키며, 음경의 작은 혈관들인 내음부동맥, 총음경동맥, 해면체동 맥에 먼저 영향을 미치고 차후에 더 큰 동맥인 심혈관 동 맥에 영향을 미친다는 것이 합리적으로 생각된다. 또한, 혈관성 발기부전은 심혈관계 질환의 초기 증상으로 나타 날 수 있으며, 역학적 연구 결과 심혈관계 질환 발생의 초 기 표지자로도 보고되고 있다[26]. 따라서 만약 젊었을 때, 치주질환에 이환된다면, 40 대 이상의 중년이 되었을 때, 혈관성 발기부전의 가능성이 증가할 것으로 고려되며, 심 혈관 질환의 유병률 역시 높아질 것으로 예상되나, 이에 대한 연구가 부족한 실정으로 이에 대해서는 차후 심도 있 는 역학적 연구가 필요할 것으로 고려된다.

본 연구는 40 대에서 70 대까지의 일반건강검진 수검자를 대상으로 치주질환과 혈관성 발기부전의 연관성을 조사하 였으며, 두 질환 사이에 상당한 연관성을 확인할 수 있었 다. 다만, 이번 연구에 사용한 건강검진코호트 데이터베이 스는 건강검진 수검자 515 만명 중 $10 \%$ 를 단순 무작위 추 출하였기 때문에 결과의 편향성이 있을 수 있다. 여기에 더하여, 치주질환과 혈관성 발기부전 모두 구체적인 진료 내역을 확인하거나 임상적 정보를 확인하지 못하였기 때 문에, 두 질환의 심도에 따른 연관성을 확인할 수 없었다. 그럼에도 불구하고, 치주질환의 진단률을 높이기 위하여 진단명과 구강검진 결과를 동시에 만족하는 대상자를 선 별하였다는 점과 40 세 이상의 주요 치주질환과 혈관성 발 기부전 진단자를 대상으로 하였다는 점, 건강보험 청구를 목적으로 실제 상병명과 일치하지 않는 주상병과 부상병 만을 입력할 경우, 제한되는 진단 기준을 구강검진 결과를
통해서 다시 확인하였다는 점에서 본 연구의 의미를 찾을 수 있다. 치주질환이 혈관성 발기부전과 직접적으로나 간 접적으로 연관성이 있다고 고려된다면, 양치질, 치실, 치간 칫솔의 사용과 예방적 보험 스케일링을 포함한 적극적인 치주 관리를 통해서 혈관성 발기부전의 유병률이나 심도 를 감소시킬 수 있을 것으로 고려되는 것 역시 임상적으 로 의미가 있을 것이라고 생각된다[27].

\section{결 론}

전 세계적으로 치주질환과 혈관성 발기부전 사이의 관 계를 파악하려는 연구들이 증가하고 있으며, 실제로 상당 히 많은 연구 결과들이 치주질환과 혈관성 발기부전과의 연관성에 대하여 언급하고 있다. 본 연구에서는 2016년 발 표된 최신의 건강검진코호트 데이터베이스를 이용하여 40 세 이상의 성인 남성을 대상으로 치주질환과 혈관성 발기 부전과의 연관성을 조사하였으며, 통계적으로 유의하게 연관이 있음을 확인할 수 있었다. 앞으로 치주질환과 혈관 성 발기부전 사이의 직접적인 연관성을 밝힐 수 있는 기 저 메커니즘에 대한 연구가 지속적으로 필요할 것으로 고 려된다.

\section{감사의 글}

This work was supported by the Students' Association of the Graduate School of Yonsei University funded by the Graduate School of Yonsei University and Basic Science Research Program through the National Research Foundation of Korea (NRF) funded by the Ministry of Science, ICT \& Future Planning (NRF-2017R1C1B5014849).

\section{Conflict of Interest}

The authors declare that they have no competing interests.

\section{ORCID}

$\begin{array}{ll}\text { Jae-Hong Lee } & 0000-0002-2375-0141 \\ \text { Yeon-Tae Kim } & 0000-0001-7209-3208 \\ \text { Jung-Kyu Choi } & 0000-0001-5176-0534 \\ \text { Seong-Nyum Jeong } & \text { 0000-0003-4890-989X } \\ \text { Seong-Ho Choi } & 0000-0001-6704-6124\end{array}$




\section{References}

1. Pihlstrom BL, Michalowicz BS, Johnson NW. Periodontal diseases. Lancet 2005;366:1809-1820. doi: 10.1016/ S0140-6736(05)67728-8.

2. Health Insurance Review and Assessment Service. Outpatient disease statistics. https://www.hira.or.kr/eng/. Accessed on 17 October 2016.

3. NIH Consensus Conference. Impotence. NIH Consensus Development Panel on Impotence. JAMA 1993;270:8390. doi: 10.1001/jama.1993.03510010089036.

4. Cho YJ, Hwang HS, Park HK, Jeong JG. Prevalence of Erectile Dysfunction and Utilization of Sexual Counseling in Community Family Medicine Clinics. Korean J Fam Med 2009;30:617-625. doi: 10.4082/kjfm.2009.30. 8.617.

5. Feldman HA, Johannes CB, Derby CA, Kleinman KP, Mohr BA, Araujo AB, McKinlay JB. Erectile dysfunction and coronary risk factors: prospective results from the Massachusetts male aging study. Prev Med 2000;30:328338. doi: 10.1006/pmed.2000.0643.

6. Aversa A, Bruzziches R, Francomano D, Natali M, Gareri P, Spera G. Endothelial dysfunction and erectile dysfunction in the aging man. Int $\mathrm{J}$ Urol 2010;17:38-47. doi: 10.1111/j.1442-2042.2009.02426.x.

7. Lai H, Lo MT, Wang PE, Wang TT, Chen THH, Wu GHM. A community-based epidemiological study of periodontal disease in Keelung, Taiwan: a model from Keelung community-based integrated screening programme. J Clin Periodontol 2007;34:851-859. doi: 10.1111/ j.1600-051X.2007.01121.x.

8. Sharma A, Pradeep AR, Raju PA. Association between chronic periodontitis and vasculogenic erectile dysfunction. J Periodontol 2011;82:1665-1669. doi: 10.1902/ jop.2011.110049.

9. Kawanishi, Y, Lee KS, Kimura K, Koizumi T, Nakatsuji H, Kojima K, Sogou T. Screening of ischemic heart disease with cavernous artery blood flow in erectile dysfunctional patients. Int J Impot Res 2001;13:100-103. doi: 10.1038/sj.ijir.3900642.

10. Solomon H, Man JW, Jackson G. Erectile dysfunction and the cardiovascular patient: endothelial dysfunction is the common denominator. Heart 2003;89:251-253. doi: 10.1136/heart.89.5.560.

11. Armitage GC. Development of a classification system for periodontal diseases and conditions. Ann Periodontol 1999;4:1-6.

12. 1999 International International Workshop for a Classification of Periodontal Diseases and Conditions. Papers. Oak Brook, Illinois, October 30-November 2, 1999. Ann Periodontol 1999;4:i, 1-112.
13. Eke PI, Dye BA, Wei L, Slade GD, Thornton-Evans GO, Borgnakke WS, Genco RJ. Update on Prevalence of Periodontitis in Adults in the United States: NHANES 2009 to 2012. J Periodontol 2015;86:611-622. doi: 10.1902/jop.2015.140520.

14. Lee JH, Lee JS, Choi JK, Kweon HI, Kim YT, Choi SH. National dental policies and socio-demographic factors affecting changes in the incidence of periodontal treatments in Korean: A nationwide population-based retrospective cohort study from 2002-2013. BMC Oral Health 2016;16:118. doi: 10.1186/s12903-016-0310-0.

15. Keller JJ, Chung SD, Lin HC. A nationwide populationbased study on the association between chronic periodontitis and erectile dysfunction. J Clin Periodontol 2012;39:507-512. doi: 10.1111/j.1600-051X.2012.01879.x.

16. Oguz F, Eltas A, Beytur A, Akdemir E, Uslu MO, Gunes A. Is There a Relationship Between Chronic Periodontitis and Erectile Dysfunction? J Sex Med 2013;10:838843. doi: 10.1111/j.1743-6109.2012.02974.x.

17. Lee JH, Lee JS, Park JY, Choi JK, Kim DW, Kim YT, Choi SH. Association of Lifestyle-Related Comorbidities With Periodontitis: A Nationwide Cohort Study in Korea. Medicine 2015;94:e1567. doi: 10.1097/MD.0000000000001567.

18. Lee JH, Choi JK, Kim SH, Cho KH, Kim YT, Choi SH, Jung UW, Association between periodontal flap surgery for periodontitis and vasculogenic erectile dysfunction in Koreans: a nationwide population-based retrospective cohort study, 2002-2013. J Periodontal Implant Sci 2017; 47:e12. doi: 10.5051/jpis.2017.47.e12.

19. Zhang B, Khalaf H, Sirsjo A, Bengtsson T. Gingipains from the Periodontal Pathogen Porphyromonas gingivalis Play a Significant Role in Regulation of Angiopoietin 1 and Angiopoietin 2 in Human Aortic Smooth Muscle Cells. Infect Immun 2015;83:4256-4265. doi: 10.1128/ IAI.00498-15.

20. Bretz WA, Weyant RJ, Corby PM, Ren D, Weissfeld L, Kritchevsky SB, Newman AB. Systemic inflammatory markers, periodontal diseases, and periodontal infections in an elderly population. J Am Geriatr Soc 2005;53: 15321537. doi: 10.1111/j.1532-5415.2005.53468.x.

21. Kozarov EV, Dorn BR, Shelburne CE, Dunn WA, ProgulskeFox A. Human atherosclerotic plaque contains viable invasive Actinobacillus actinomycetemcomitans and Porphyromonas gingivalis. Arterioscler Thromb Vasc Biol 2005;25:e17-e18. doi: 10.1161/01.ATV.0000155018. $67835.1 \mathrm{a}$.

22. Zuo ZL, Jiang J, Jiang R, Chen F, Liu JX, Yang HF, Cheng, Y. Effect of Periodontitis on Erectile Function and Its Possible Mechanism. J Sex Med 2011;8:2598-2605. doi: 10.1111/j.1743-6109.2011.02361.x.

23. Maas R, Schwedhelm E, Albsmeier J, Boger RH. The pathophysiology of erectile dysfunction related to endothelial dysfunction and mediators of vascular function. 
Vasc Med (London, England) 2002;7:213-225. doi: 10.1191/1358863x02vm429ra.

24. Tonetti MS, D'Aiuto F, Nibali L, Donald A, Storry C, Parkar M, Deanfield J. Treatment of periodontitis and endothelial function. N Eng J Med 2007;356:911-920. doi: 10.1056/NEJMoa063186.

25. Eltas A, Oguz F, Uslu MO, Akdemir E. The effect of periodontal treatment in improving erectile dysfunction: a randomized controlled trial. J Clin Periodontol 2013;
40:148-154. doi: 10.1111/jcpe. 12039.

26. Vlachopoulos C, Ioakeimidis N, Terentes-Printzios D, Stefanadis C. The triad: erectile dysfunction-endothelial dysfunction-cardiovascular disease. Curr Pharm Des 2008;14:3700-3714. doi: 10.2174/138161208786898716.

27. Liu LH, Li EM, Zhong SL, Li YQ, Yang ZY, Kang R, Zhao ZG. Chronic periodontitis and the risk of erectile dysfunction: a systematic review and meta-analysis. Int J Impot Res 2017;29:43-48. doi: 10.1038/ijir.2016.43. 